\title{
Properties of Cement Concrete Reinforced With Bamboo-Strip-Mat
}

\author{
Dr.M.B.Varma ${ }^{1}$ \\ ${ }^{1}$ Assosiate Professor, Applied Mechanics Department Government College of Engineering, Aurangabad, \\ Maharashtra, India
}

\begin{abstract}
Bamboo is very cheap, easily available, and available in ample quantity. Bamboo is cultivated in farm by farmers. Bamboo is having very good mechanical properties which attract many researchers to use it as reinforcing material in concrete. From bamboo small thin strips were prepared. These strips were tied together in two directions to form a bamboo-strip-mat. All these strips while making bamboo-strip-mat was tied together with small thin Mild Steel wire to ensure their position in mat formation. In this paper study is presented using bamboo-strip-mat as reinforcement in cement concrete prismatic section at bottom side. Concrete beams thus produced in laboratory were tested in flexure; results obtained were presented in this paper. Bamboo strips were prepared from old age bamboo.
\end{abstract}

Keywords: Bamboo-strip-mat, flexure, deflection

\section{Bamboo as a Construction Material [1]}

\section{Introduction}

Bamboo reaches its full growth in just a few months and reaches its maximum mechanical strength in just few years. Its abundance in tropical and subtropical regions makes it an economically advantageous material.

\section{Comparison of Steel with bamboo [2]}

One of the properties that would make bamboo a good substitute to steel in reinforced concrete is its strength. The strength of bamboo is greater than most timber products which are advantageous, but it is approximately half the tensile strength [3] of steel. Bamboo is easily accessible as it grows in almost every tropical and subtropical region; this lowers the cost of construction and increases the strength of the buildings that would otherwise be unreinforced. One major problem with bamboo is that it attracts living organism such as fungi and insects. Bamboo is more prone to insects than other trees and grasses because it has a high content of nutrients. In order to combat this problem, it becomes necessary to treat bamboo to protect it from the environment. Steel does not have this problem but it also needs to be coated in order to protect it from rusting. Bamboo is very light in weight compared to steel. Due to its low modulus of elasticity, bamboo can crack and deflect more than steel reinforcement under the same conditions. BIS standards [4] can be referred to know method of testing of bamboo

\section{Prior Approach}

C.S. Verma et al [5] reported in their research paper titled Tensile Strength Analysis of whole bamboo and Layered Laminate Whole bamboo composites properties of bamboo and bamboo as reinforcement. They have studied Tensile properties of bamboo laminae, prepared from bamboo slivers, selected from different regions of bamboo culms increases from inner to outer region for any cross section and the same is experienced from bottom to top. To increase usability of bamboo like wood, layered laminate bamboo composite (LLBC) is fabricated from laminae using adhesive. The properties of LLBCs obtained were resembled with the properties of the teak wood. Fracture behaviour of laminas and LLBCs under tensile loading conditions was studied using scanning electron microscopy (SEM). They have concluded The experimental investigations show that tensile strength and Young's modulus of bamboo increases from inner to outer region across any cross section and from bottom to top of bamboo culms due to increase in volume fraction of fibers. The culms strength increases with height to compensate for the deterioration of rigidity due to the culms geometry Nodes are the weakest portion of the Culm when it comes to tensile loads. Though, it must be very strong in lateral loads because at joints, the craftsmen invariably try to place the node. Longitudinal cracking is responsible for failure on single laminae. Modes of failure indicate that fibers presents in the laminae are brittle. First matrix failure occurs followed by fibers failure of any one layer and subsequently other layers in LLBCs. Dr. Mahavir B. Varma [6] has carried out experimental study on bamboo strip reinforced concrete. He reported in his paper as for 4 bamboo strip flexural load increased by $90.5 \%$ and for beam reinforced with 6 bamboo strip $171.5 \%$ increase in flexural load compared with plain concrete beam. 


\section{Research Significance}

Many researchers have tried different material as reinforcement with concrete bamboo cheap, easily available and having good tensile strength is one of the materials as reinforcement with concrete. It is very much necessary to test the suitability of bamboo as reinforcement. Practical study is required to check compatibility of bamboo with concrete as a composite structure. Various researchers [7] have tried bamboo in different shapes. Present study is carried out by preparing bamboo strip mat and tried with concrete as reinforcement. Main goal to achieve of this study was houses to poor people.

\section{Experimental Investigation}

Bamboo-strip-mat specimen from whole bamboo, bamboo strips were cut. All these bamboo strips were tied together as shown in Figure 1.

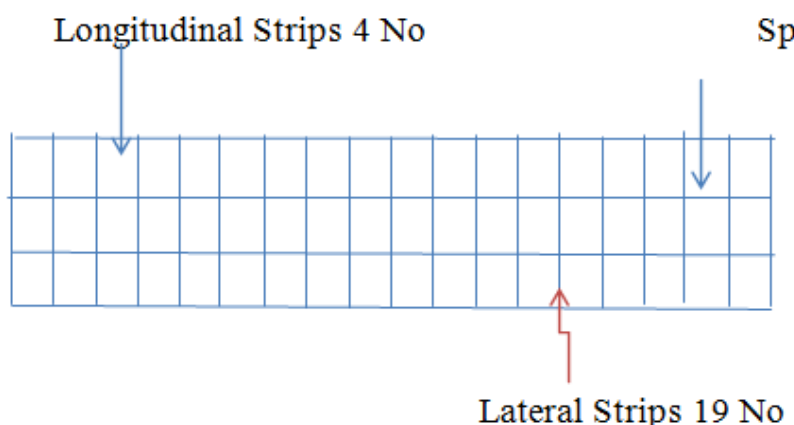

Spacing $20 \mathrm{~mm}$ Both Side

Figure 1: The Bamboo-Strip-Mat

Thus the bamboo-strip-mat was prepared. (Figure 2)

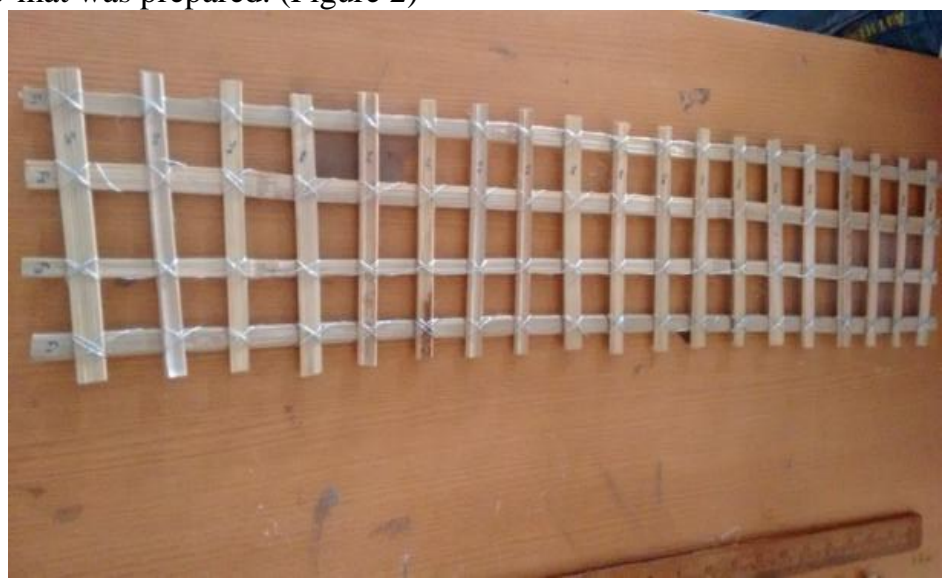

Figure 2: Typical Bamboo-Strip-Mat

This bamboo-strip-mat (figure 2) was used in practical study.

\section{Details of bamboo-strip-mat}

Longitudinal length of bamboo strips $=680 \mathrm{~mm}$

No. longitudinal bamboo strips $=4$

Lateral length of bamboo strip $=140 \mathrm{~mm}$

Lateral bamboo strips $=19$

Total number of bamboo-strip-mats used for this study was 6 and their details are tabulated in Table no. 1

Table 1: Details of Bamboo Strip Mat

\begin{tabular}{|c|c|c|c|c|}
\hline Mat No & $\begin{array}{c}\text { Weight of Longitudinal } \\
\text { Strips gm. }\end{array}$ & $\begin{array}{c}\text { Weight of Lateral } \\
\text { Strips gm. }\end{array}$ & $\begin{array}{c}\text { Weight of Steel } \\
\text { Wire gm. }\end{array}$ & Total Weight gm. \\
\hline 01 & 36 & 38 & 30 & 104 \\
\hline 02 & 36 & 35 & 26 & 97 \\
\hline 03 & 36 & 35 & 25 & 94 \\
\hline 04 & 35 & 36 & 25 & 101 \\
\hline 05 & 34 & 36 & 26 & 96 \\
\hline 06 & 37 & 35 & 27 & 99 \\
\hline
\end{tabular}




\section{Casting of Bamboo Reinforcement beam}

For casting of beams cement concrete, bamboo-strip-mat and moulds were used.

Materials

OPC, Natural sand and $20 \mathrm{~mm}(3 / 4 \mathrm{inch}), 12 \mathrm{~mm}(1 / 2 \mathrm{inch})$ stone aggregates from crusher and potable water along with Bamboo-strip-marts were used for this study.

\section{Specimens}

Total 6 test specimens of plain concrete were caste based on nominal concrete mix design (Table no.2) sample of size $15 \mathrm{~cm} \times 15 \mathrm{~cm} \times 15 \mathrm{~cm}, 5$ beam specimens were caste of size $15 \times 15 \times 70 \mathrm{~cm}$

Table 2: Proportion of ingredients of cement concrete grade M 20

\begin{tabular}{|c|l|l|l|}
\hline Cement & F.A. & C.A. & Water \\
\hline $300 \mathrm{Kg}$ & $670 \mathrm{Kg}$ & $1236 \mathrm{Kg}$ & $150 \mathrm{Ltr}$. \\
\hline 1 & 2.23 & 4.12 & 0.5 \\
\hline
\end{tabular}

Procedure adopted for casting of beam:-

1. Five beam specimens were caste of size $150 \times 150 \times 700 \mathrm{~mm}$

2. Bamboo bamboo-strip-mat was kept in Mould and first layer of concrete was filled with fresh concrete to one third of its height and vibrated on table vibrator.

3. Then the second layer is kept and filled with fresh concrete again vibrated on table.

4. The filling of concrete and vibrating is done in 3 steps to attain specified condition.

5. Specimens were then removed from vibrating table to casting room floor for initial curing.

\section{Beam no. 01: Plain Concrete Beam (Figure 3) (P)}

This beam is cast only with the concrete without any reinforcement and tested after 28 days. Specifications:

1. Size of the Mould: $700 \times 150 \times 150 \mathrm{~mm}$

2. Empty Weight of the Mould : $45.55 \mathrm{~kg}$

3. Weight of the Mould with concrete $: 88.05 \mathrm{~kg}$

4. Weight of the beam after 28 days $: 41.70 \mathrm{~kg}$
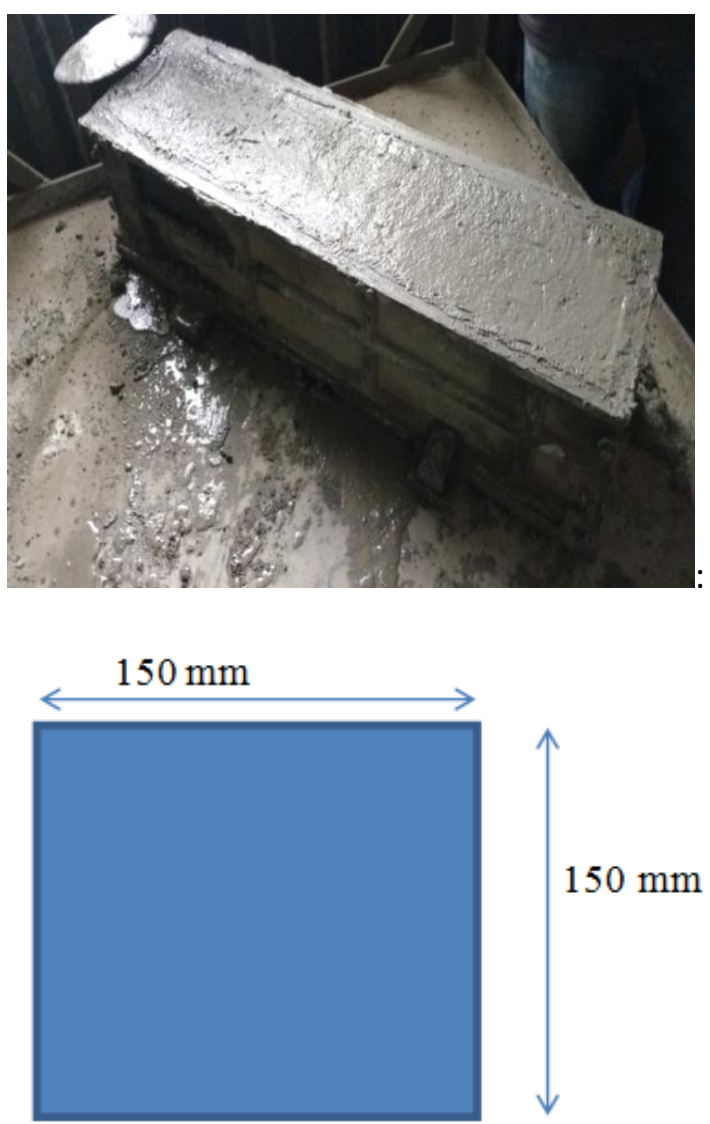

Figure 3: Plain Concrete Beam 
Beam no. 2: Beam with one TMT bar

This beam is cast with one TMT steel bar, placed at center with $20 \mathrm{~mm}$ nominal cover from bottom and tested after 28 days of water curing.

Specifications:

1. Size of the Mould: $700 \times 150 \times 150 \mathrm{~mm}$

2. Empty Weight of the Mould : $45.55 \mathrm{~kg}$

3. Weight of the Mould with concrete $: 87.55 \mathrm{~kg}$

4. Weight of the beam after 28 days $: 41.65 \mathrm{~kg}$
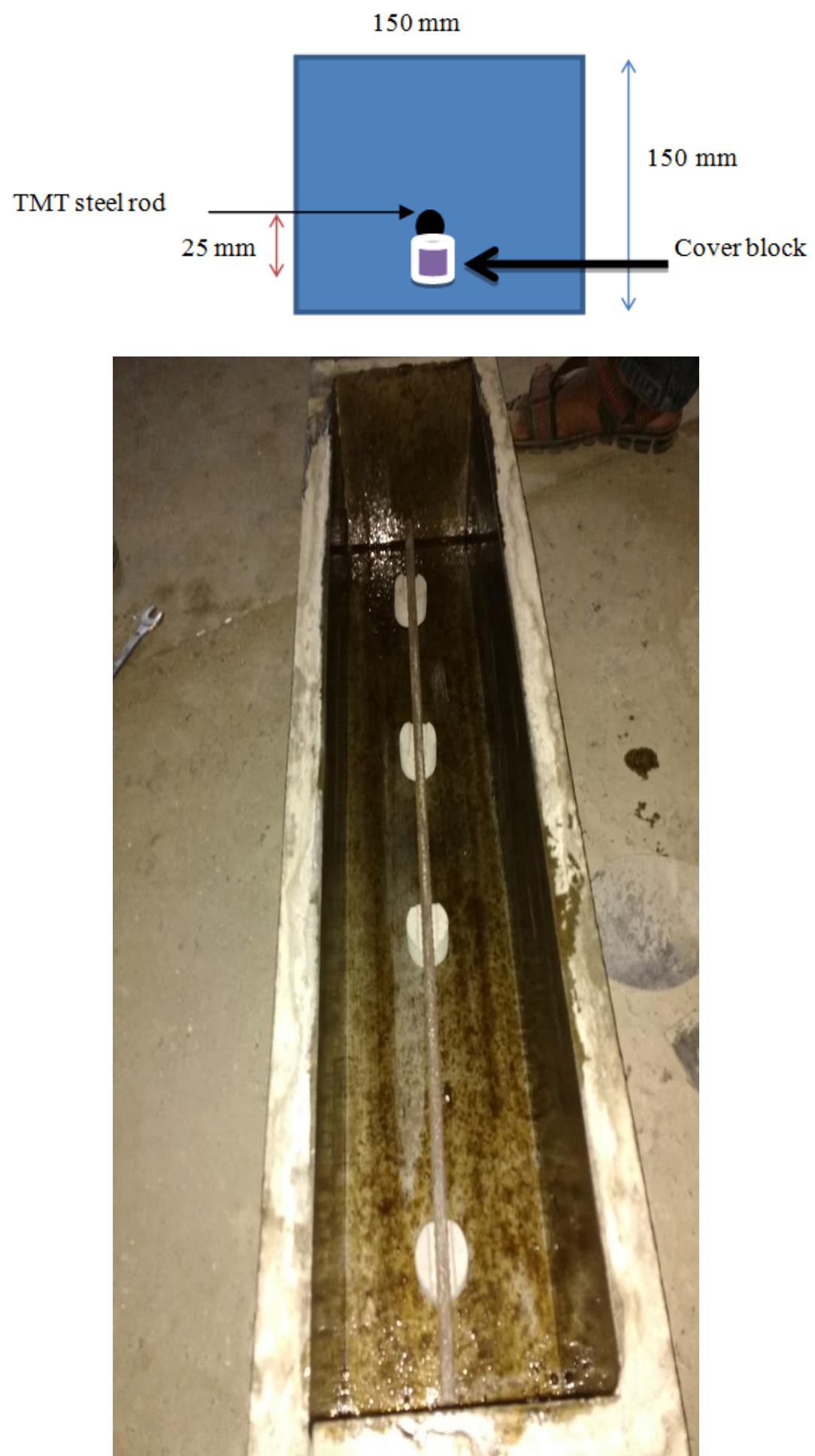

Figure 4: Arrangement of one TMT steel bar in Beam mould 
Beam no. 3: Beam with single bamboo-strip-mat (1 Mat) (Figure 5)

This beam was cast with single bamboo-strip-mat, placed at center with $25 \mathrm{~mm}$ nominal cover from bottom.

Concrete was filled in Mould. On next day remolded and kept for 28 days water curing and tested after 28 days.

Specifications:

1. Size of the Mould: $700 \times 150 \times 150 \mathrm{~mm}$

2. Empty Weight of the Mould : $45.55 \mathrm{~kg}$

3. Weight of the Mould with concrete $: 87.80 \mathrm{~kg}$

4. Weight of the beam after 28 days : $41.50 \mathrm{~kg}$

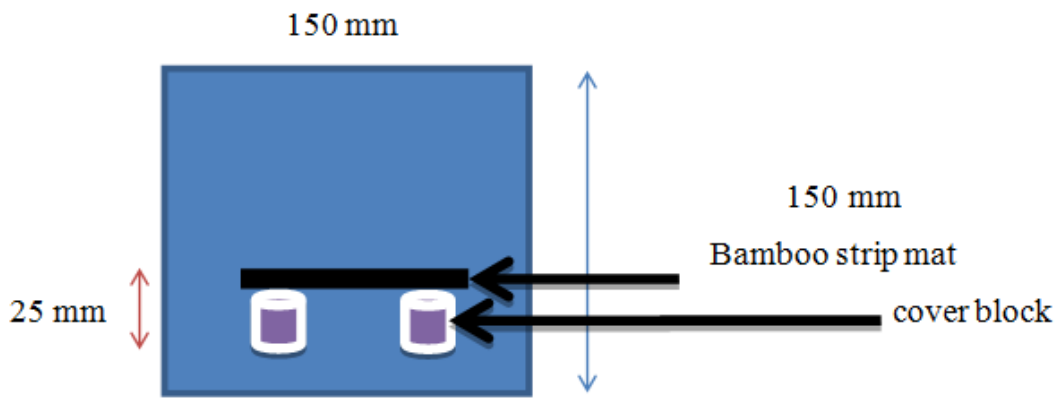

Cross Section of 1 Mat Beam

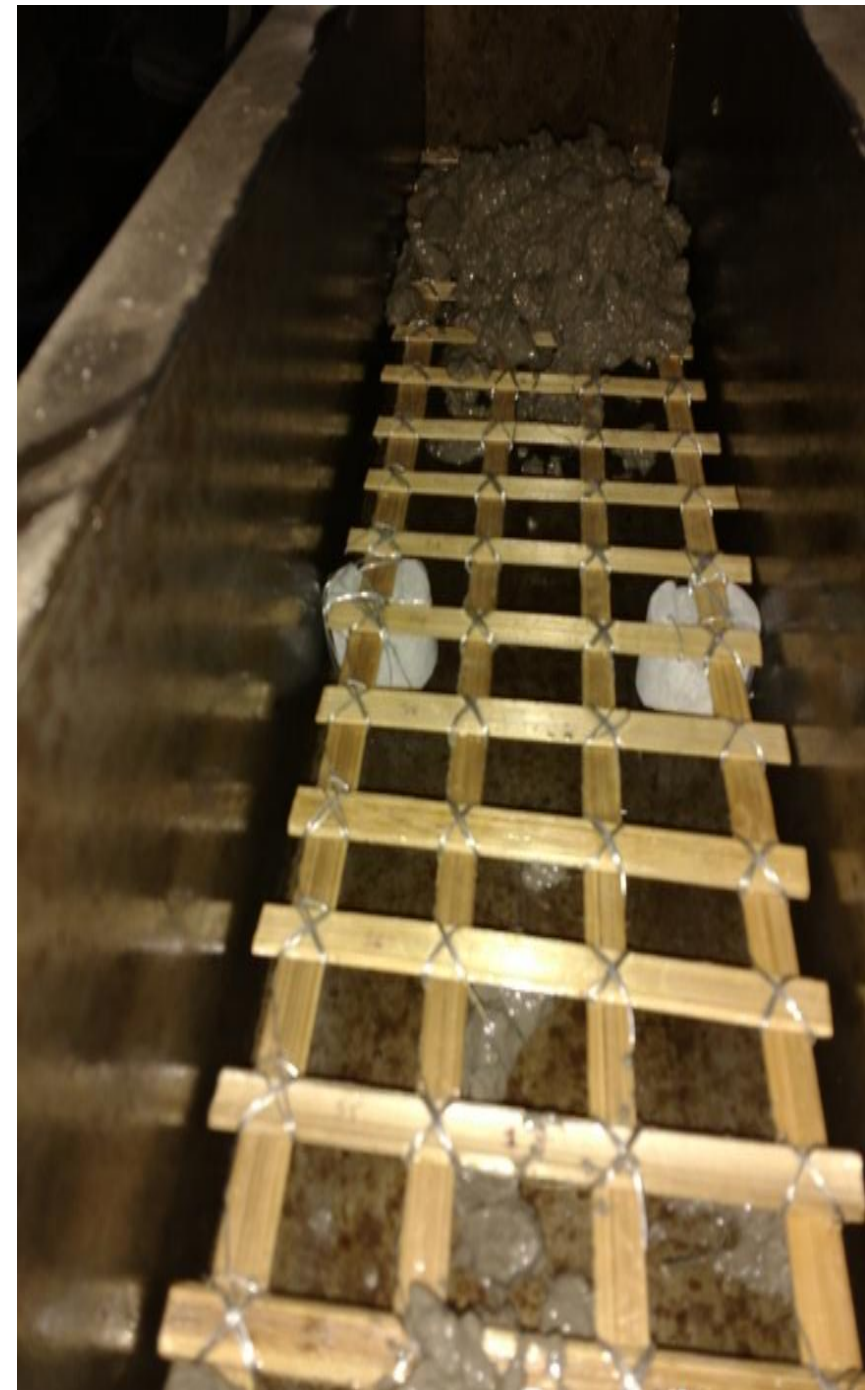

Figure 5: Bamboo-strip-mat Arrangement in Beam (1 mat) 
Beam no. 4: Beam with 2 bamboo-strip-mats (2 Mat) (Figure 6)

This beam was cast with 2 bamboo-strip-mat of bamboo-strip-mat, first bamboo-strip-mat placed at bottom of the beam with $25 \mathrm{~mm}$ nominal cover by using the concrete cover block and second bamboo-strip-mat placed over first bamboo-strip-mat with nominal cover $15 \mathrm{~mm}$ (0.59 in) and tested after 28 days.

Specifications:

1. Size of the Mould: $700 \times 150 \times 150 \mathrm{~mm}$

2. Empty Weight of the Mould : $44.95 \mathrm{~kg}$

3. Weight of the Mould with concrete $: 86.00 \mathrm{~kg}$

4. Weight of the beam after 28 days : $40.55 \mathrm{~kg}$



\section{Cross Section of 2 Mat Beam}

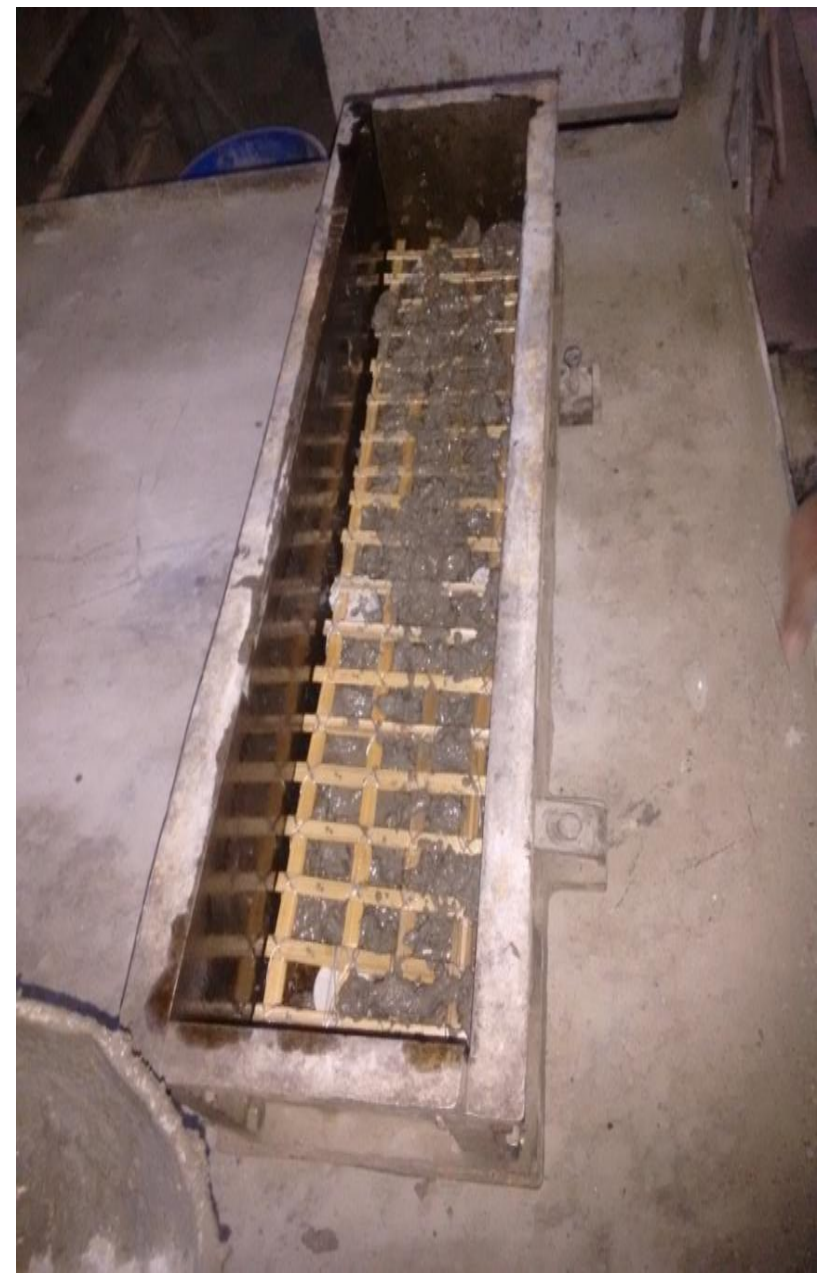

Figure 6: Bamboo-strip-mat Arrangement in Beam (2 mat) 


\section{Beam no. 5: Beam with 3 bamboo-strip-mats (3 Mat) (Figure 7)}

This beam was cast with 3 bamboo-strip-mats; first bamboo-strip-mat placed at bottom of the beam with $25 \mathrm{~mm}$ nominal cover by using the concrete cover block and second bamboo-strip-mat placed over first bamboo-strip-mat with nominal cover $15 \mathrm{~mm}$ and third bamboo-strip-bamboo-strip-mat was placed over second bamboo-strip-mat with nominal cover $15 \mathrm{~mm}$ and tested after 28 days.

\section{Specifications:}

1. Size of the Mould: $700 \times 150 \times 150 \mathrm{~mm}$

2. Empty Weight of the Mould : $45.55 \mathrm{~kg}$

3. Weight of the Mould with concrete $: 87.35 \mathrm{~kg}$

4. Weight of the beam after 28 days : $41.75 \mathrm{~kg}$

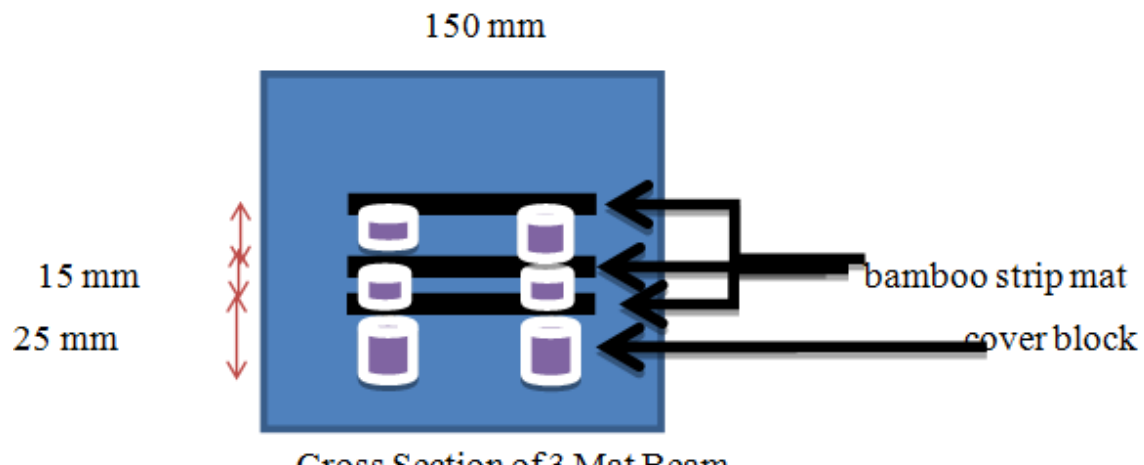

Cross Section of 3 Mat Beam



Figure 7: Bamboo-strip-mat Arrangement in Beam (3 mat) 


\section{Items of investigation}

To confirm the grade of concrete cubes were cast and tested for compressive strength. To study the feasibility of the bamboo-trip-mat as reinforcement in the cement concrete beam, beams reinforced with bamboo-strip-mat was cast and the following tests were performed:

1. Compression Test on plain concrete cube.

2. Flexural test on the plain cement concrete beam

3. Flexural test on the one TMT steel bar reinforced cement concrete beam.

4. Flexural test on the single bamboo-strip-mat reinforced cement concrete beam.

5. Flexural test on the double bamboo-strip-mat reinforced cement concrete beam.

6. Flexural test on the Triple bamboo-strip-mat reinforced cement concrete beam.

Above mentioned six tests were carried out in laboratory on specimens made from concrete and bamboo-stripmat

\section{Analytical investigation}

Initially compressive strength of concrete was recorded. Then beams were tested if flexure tests.

Compression Test on plain concrete cube

$15 \mathrm{~cm}$ size of cement concrete cubes was tested under compression testing machine to get compressive strength of concrete after 28 days water curing. Results obtained were tabulated in Table 3.

Table 3: Compressive Strength of Plain Concrete

\begin{tabular}{|c|c|c|c|c|}
\hline Cube & Weight of cube Kg & Curing (days) & Comp. strength MPa & Av. Comp. strength MPa \\
\hline 1 & 8.95 & \multirow{2}{*}{7} & 18 & 17.88 \\
& 9.15 & & 17.55 & \\
\hline 3 & 8.6 & \multirow{2}{*}{28} & 18.1 & \multirow{2}{*}{29.92} \\
\hline 4 & 8.41 & & 28.88 & \\
\hline 5 & 8.24 & & 29.77 & \\
\hline 6 & 8.56 & & 31.11 & \\
\hline
\end{tabular}

\section{Flexural strength test on concrete beam}

To check and compare the flexural strength of concrete beam reinforced with bamboo-strip-mat, steel and plain concrete beam the flexural test (Figure 8) was carried out.

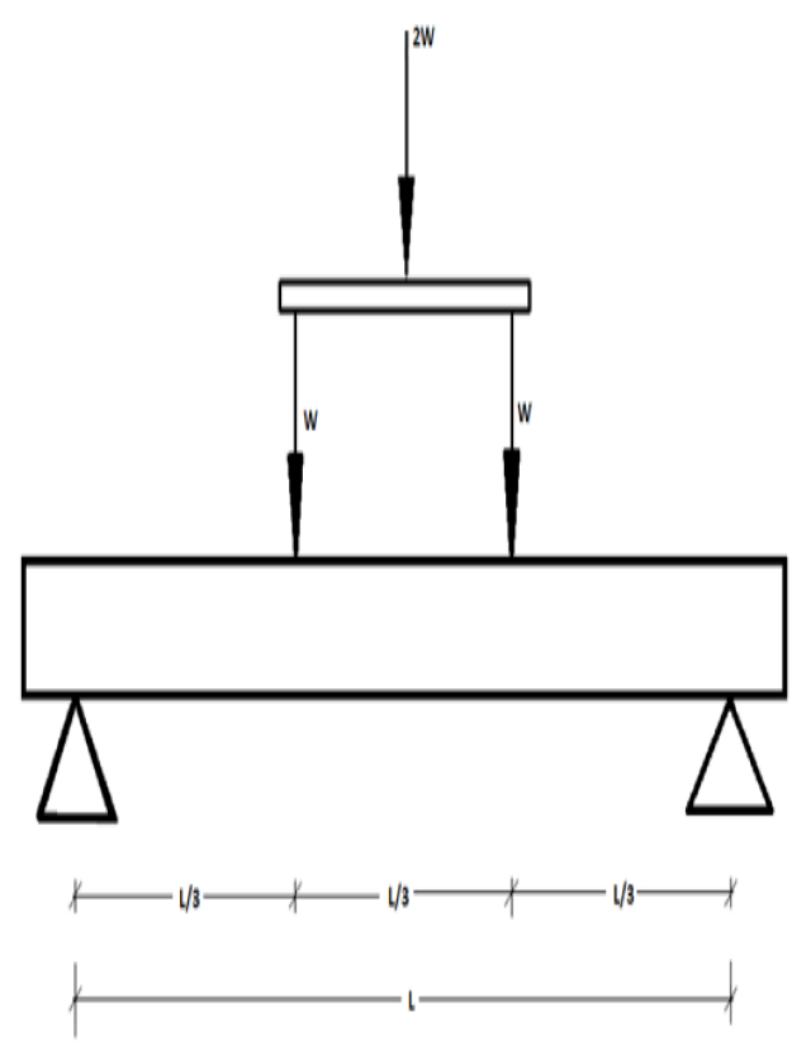

Figure 8: Schematic Presentation of Four Point Load Test 


\section{Four point loading in flexure test}

Figure 9 shows that beam specimens loaded by third-point loading produced by a hydraulic jack supported on a rigid steel frame.

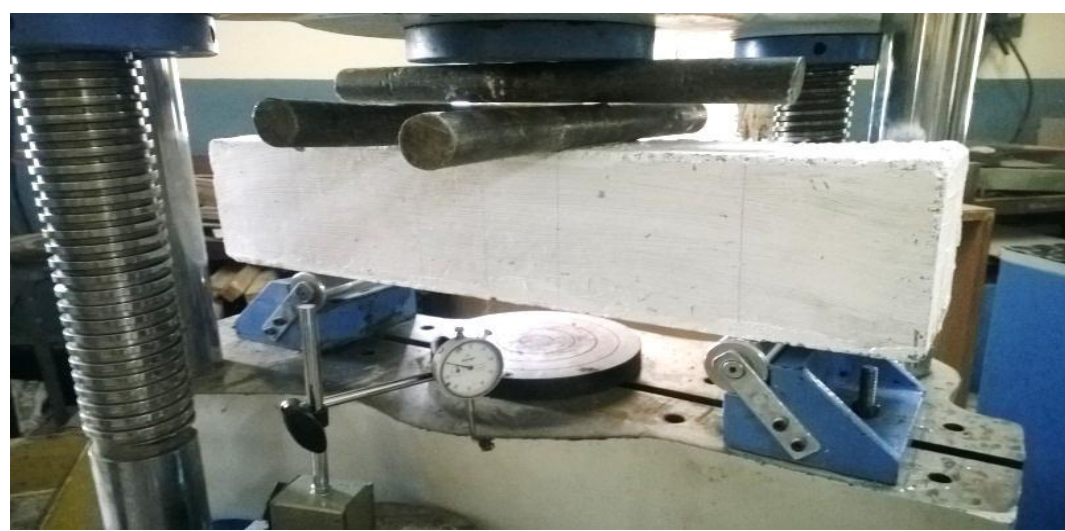

Figure 9: Experimental Setup of Four Point Load Test



Figure 10: Placing Specimen for Four Point Loading Test

Spreader beam transfer the load symmetrically to ensure pure bending in the mid-span of the beams. A dial gauge of LC $0.01 \mathrm{~mm}$ was used to record the central deflection of the beams. Load is increased slowly and a dial gauge is attached to machine. As the load increases deflection on dial gauge is simultaneously recorded. The readings of first crack and breaking of bamboo mat are too recorded. After the beam gets fully cracked or once the noise of breaking of bamboo is heard then stop recording, or one can record final reading till full breakage of beam. In this way a graph of load vs. deflection is plotted (figure 11) and compared with readings of remaining bamboos. Figure 12 shows that the first crack was developed by the application of load, in the beam.

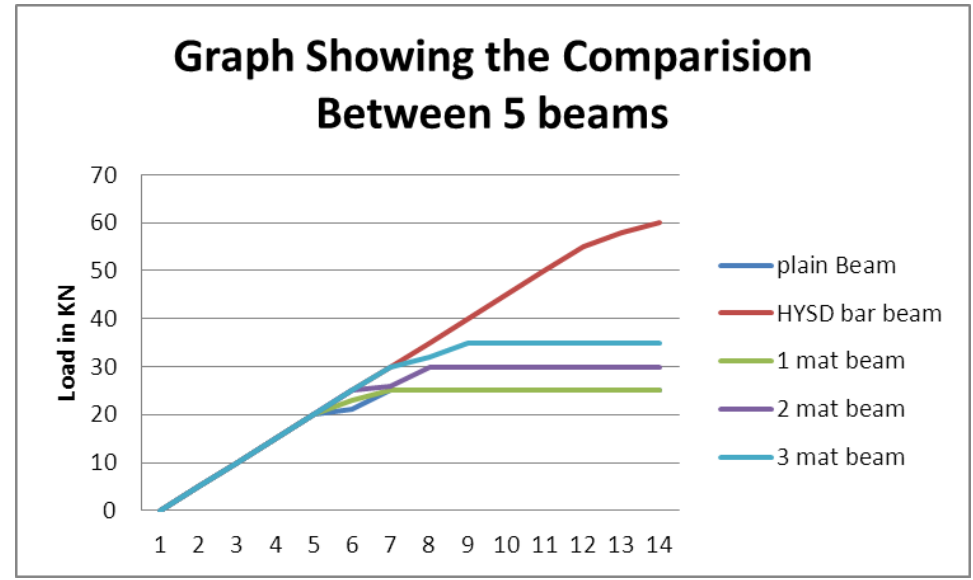

Figure 11: Graph Showing Deflection (mm) Vs. Load (KN) of 5 Beams 


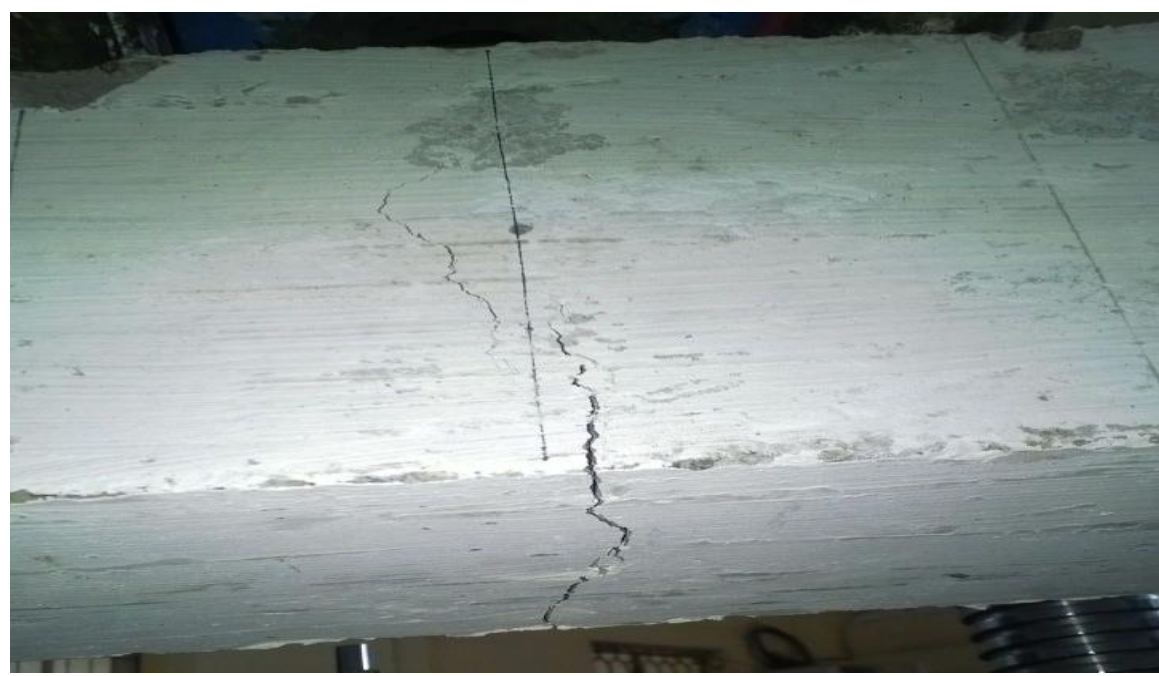

Figure 12: Failure of Plain Concrete Beam (1)



Figure 13: Failure of Plain Concrete Beam (2)

The failure of beam having 1 TMT rod in this type of the beam the first crack initiated was flexural which developed in the middle third portion of the beam.

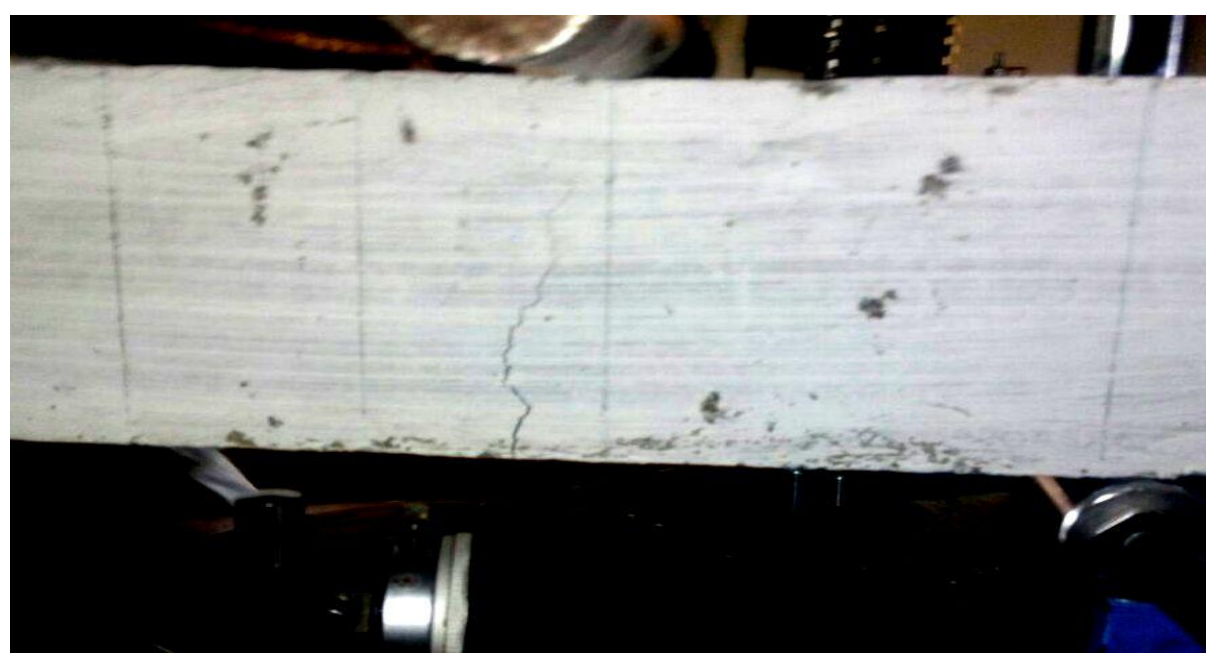

Figure 14: Concrete Beam with Single TMT Steel Rod 


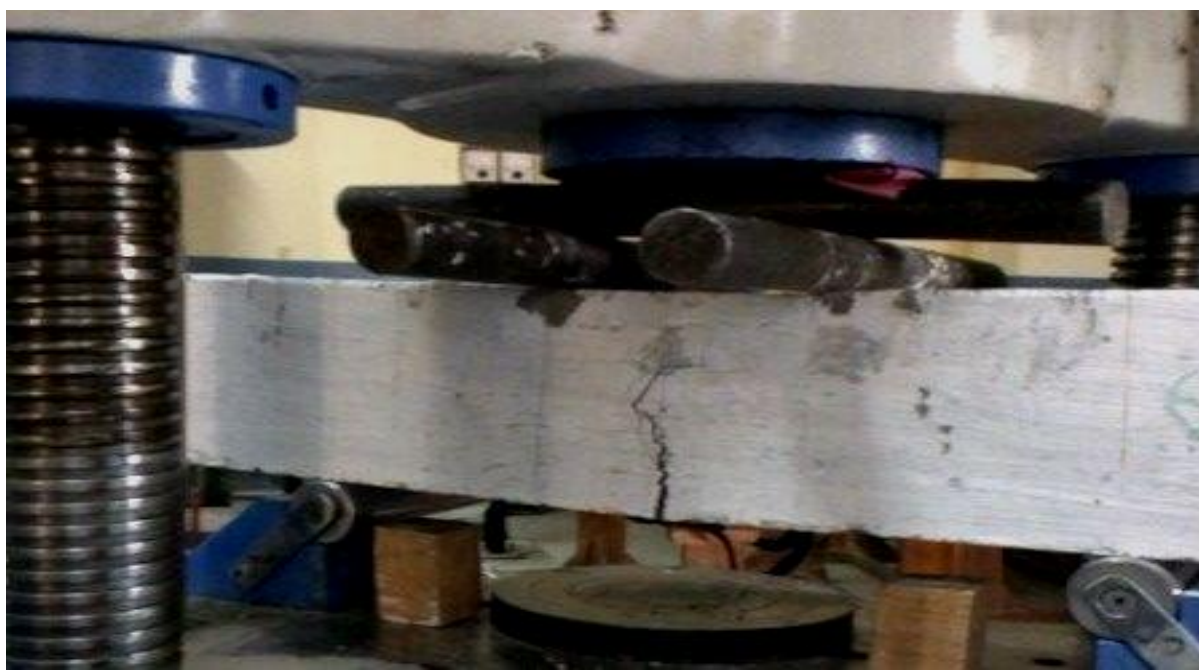

Figure 15: Four Point Loading Test on 1 Bamboo-strip-mat Concrete Beam

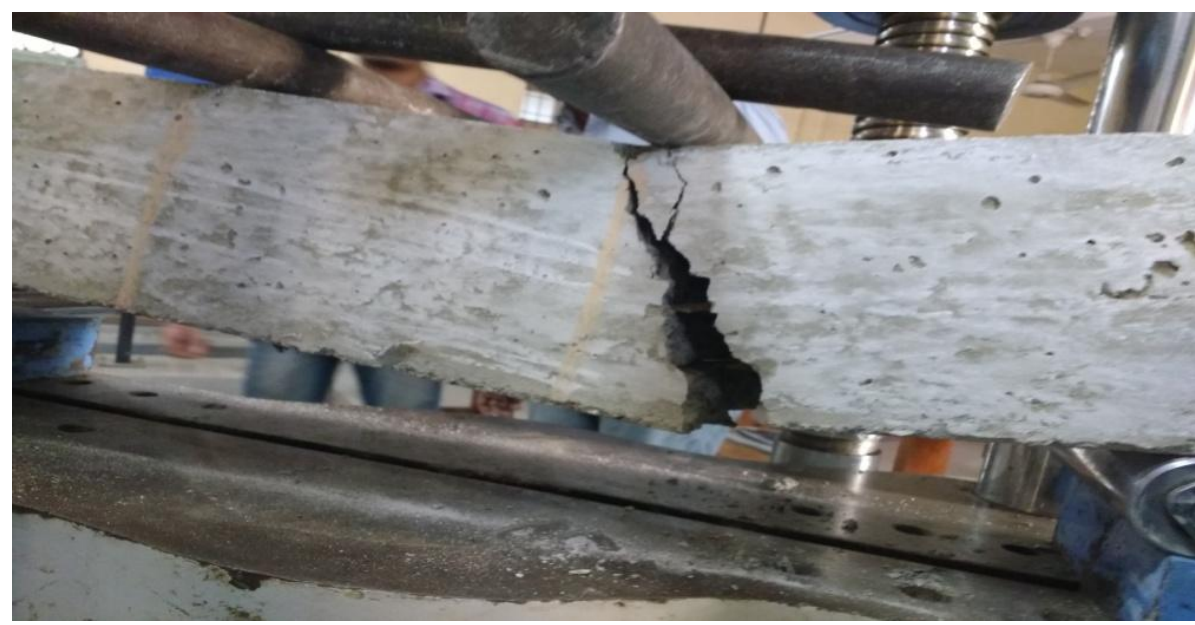

Figure 16: Four Point Loading Test on 2 Bamboo-strip-mat Concrete Beam (1)

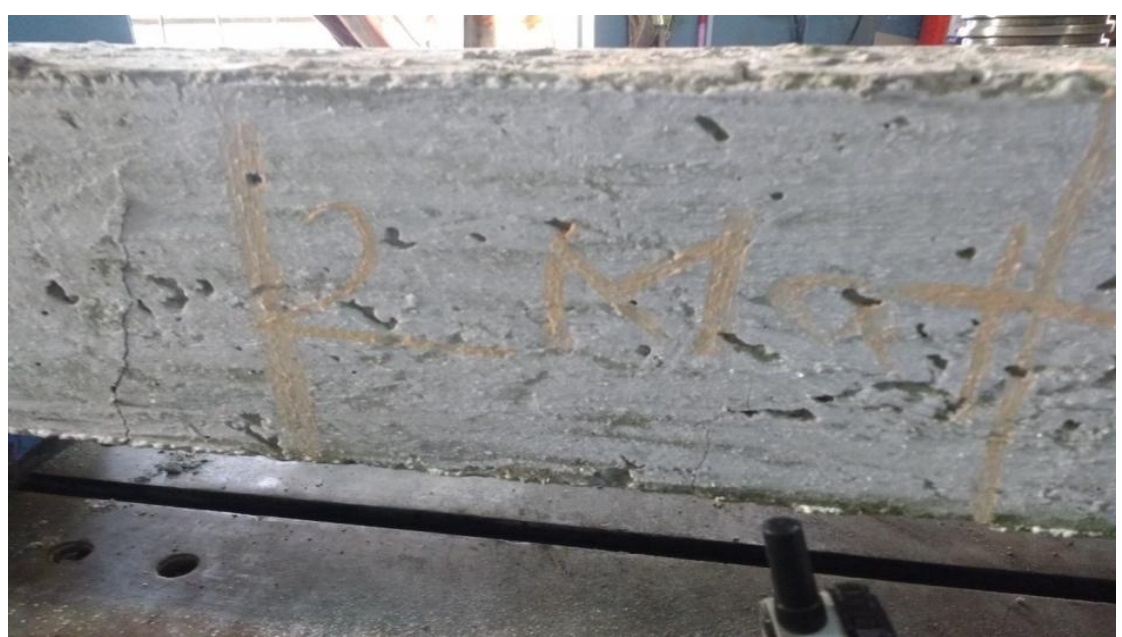

Figure 17: Four Point Loading Test on 2 Bamboo-strip-mat Concrete Beam (2)

The failure of beam having 1 bamboo-strip-mat of bamboo in this type of the beam the first crack initiated was flexural which developed in the middle third portion of the beam. The first crack was developed by the application of load, in the beam. The failure of beam having 2 bamboo-strip-mat of bamboos in this type of the beam the first crack initiated were flexural which developed in the middle third portion of the beam.

The shear crack generated at the bottom of the beam element near the support, and propagated towards the middle third portion. The crack widened with the increase in the load 
The crack travelled vertically upwards towards the point of load application. The crack widened with the increase in the load. The flexure crack was recorded. The beam suddenly failed at the ultimate load. The beam showed the brittle failure.



Figure 18: Four Point Loading Test on 3 Bamboo-strip-mat Concrete Beam

Experimental results and discussion

1. Plain concrete beam-Max. Load carrying capacity of beam $=21.00 \mathrm{KN}$

2. One TMT bar beam-Max. Load carrying capacity of beam $=58.00 \mathrm{KN}$

3. 1 bamboo-strip-mat beam-Max. Load carrying capacity of beam $=23.00 \mathrm{KN}$

4. 2 bamboo-strip-mat beam-Max. Load carrying capacity of beam $=26.00 \mathrm{KN}$

5. 3 bamboo-strip-mat beam-Max. Load carrying capacity of beam $=32.00 \mathrm{KN}$

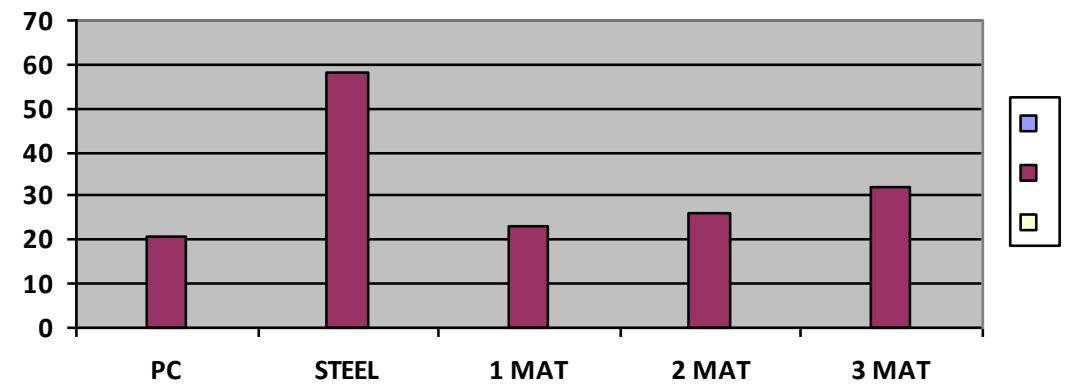

Figure 19: Chart Showing Beam vs. Ultimate Flexural Failure Load

\section{Comparison of results:}

Failure load in flexural test was compared with plain concrete beam. (Table 4)

Table 4: Comparison of Failure Load in Flexure of All Beams

\begin{tabular}{|l|l|l|l|l|}
\hline Specimen & $\begin{array}{l}\text { FAILURE } \\
\text { Load taken } \\
\text { KN }\end{array}$ & $\begin{array}{l}\text { \% increase in } \\
\text { Failure } \\
\text { load(PC) }\end{array}$ & $\begin{array}{l}\text { \% increase in } \\
\text { Failure load(amongst } \\
\text { mat) }\end{array}$ & $\begin{array}{l}\text { \% increase in } \\
\text { Failure load(amongst } \\
\text { mat) }\end{array}$ \\
\hline PC & 21 & - & - & - \\
\hline TMT & 58 & 176 & - & - \\
\hline 1-MAT & 23 & 9.5 & - & 60 \\
\hline 2-MAT & 26 & 23.8 & 13 & 55.17 \\
\hline 3-MAT & 32 & 52.38 & 39 & 44.83 \\
\hline & & & & \\
\hline
\end{tabular}

\section{Conclusion}

1. Bamboo-strip-mat reinforced beam when compared with plain concrete beam $9.5 \%, 23.8 \%$ and $52.5 \%$ increase in load in flexure was recorded it indicated that bamboo-strip-mat can be used as reinforcement in concrete construction.

2. When bamboo-strip-mat reinforced beam was compared with beam reinforced with TMT steel reinforced beam it was reported decrease in failure load of $60 \%, 55.17 \%$ and $44.83 \%$ indicating that steel cannot be 
fully replaced by bamboo-strip-mat

3. When deflection was observed it was noted as number of bamboo-strip-mat increased deflection was also increasing.

4. More effecting resin coating may increase failure load of bamboo-strip-mat as it was found during test bamboo-strip-mat was corroded.

\section{References}

[1] Sudhakar, P., Gupta, S. and Kordke, C., Bhalla, S. and Satya, S., Report of conceptual development of bamboo concrete composite structures at a typical tribal belt in India, Proc. International Conference on Modern Bamboo Structures, 28-30 October, Changsha, China, pp.65-73, (2007)

[2] Bhalla S., Sudhakar, P., Gupta, S. and Kordke, C., Wind analysis of bamboo based shed structure and design of base connection for bambocrete Column, Proc. International Conference Modern Bamboo Structures, 28-30 October, Changsha, China, pp.259-265, (2007)

[3] M.B.Varma,An attempt to test suitability of bamboo strip as a structural material,Journal os structural engineering and management,ISSN:2393-8773(online),Vo;ume 2,issue 3,oct.2015,pp.60-64

[4] M.B.Varma,State of The art: Bamboo as a structural Material,International Journal of Engineering Research,ISSN 23196890(Online)Volume no.5,Issue Special 1,Jan.2016,PP.300-303,

[5] C.S. Verma et.al, Tensile strength analysis of bamboo and layered laminate bamboo composite, International Journal of Engineering research and applications (IJERA) ISSN: 2248-622, Vol.2, Issue 2, Mar-Apr. 2012, pp.1253-1264

[6] Dr,M.B.Varma,Properties of Bamboo Strip Reinforced Concrete,International Journal of Engineering Research and Technology(IJERT),ISSN:2278-0181,Volume 4,Issue.10,October 2015,pp.1-4

[7] Ghavami K., Ultimate Load Behaviour of Bamboo-Reinforced Lightweight Concrete Beams, Cement and concrete Composites, 17, Aug 1995, pp. 281-288 